\title{
The Mediator Role of Critical Thinking Disposition in the Relationship between Perceived Problem-Solving Skills and Metacognitive Awareness of Gifted and Talented Students
}

\author{
Murat BORAN * \\ Department of Educational Sciences, Erciyes University, Kayseri, Turkey \\ ORCID: 0000-0003-4626-2404 \\ Fazilet KARAKUŞ \\ Department of Educational Sciences, Mersin University, Mersin, Turkey \\ ORCID: 0000-0002-6455-9845
}

\begin{tabular}{|c|c|}
\hline Article history & This study aims to examine relationships among critical thinking \\
\hline $\begin{array}{l}\text { Received: } \\
07.04 .2021\end{array}$ & $\begin{array}{l}\text { dispositions, perceived problem-solving skills and metacognitive } \\
\text { awareness of gifted and talented students, and to test a structural equation }\end{array}$ \\
\hline $\begin{array}{l}\text { Received in revised form: } \\
06.06 .2021\end{array}$ & $\begin{array}{l}\text { model based on these relationships. The study was conducted using the } \\
\text { correlational research design and the study group, which was selected by } \\
\text { using convenience sampling method, consisted of } 502 \text { gifted and talented }\end{array}$ \\
\hline $\begin{array}{l}\text { Accepted: } \\
21.06 .2021\end{array}$ & $\begin{array}{l}\text { students who were registered to Science and Art Centers in Adana, } \\
\text { Kayseri and Mersin, Turkey in } 2016 \text {. The data were collected through use }\end{array}$ \\
\hline Key words: & of Likert-type scales and analyzed using Lisrel 8.7 and IBM SPSS Amos \\
\hline $\begin{array}{l}\text { The gifted and talented; } \\
\text { Problem-solving; } \\
\text { Metacognitive awareness; } \\
\text { Critical thinking; } \\
\text { Structural equation model }\end{array}$ & $\begin{array}{l}25 \text { programs. Structural equation modeling was used to determine } \\
\text { structural relationships among variables. The initial findings indicated } \\
\text { that students had high levels of critical thinking dispositions, perceived } \\
\text { problem-solving skills and metacognitive awareness. The structural } \\
\text { model, which was developed based on the relationships among these } \\
\text { three variables, was confirmed. In light of the findings obtained from this } \\
\text { model, it was revealed that } 49 \% \text { of the variance in students perceived } \\
\text { problem-solving skills was explained by their metacognitive awareness, } \\
\text { and critical thinking disposition had a full mediation effect on the } \\
\text { relationship between perceived problem-solving skills and metacognitive } \\
\text { awareness. These findings were discussed in context of the related } \\
\text { literature and some suggestions for implementation and future research } \\
\text { were presented. }\end{array}$ \\
\hline
\end{tabular}

\section{Introduction}

In today's world in which possessing excellent academic qualifications is no longer enough (Carey, 2012), individuals need to have a broad set of knowledge and skills which are defined as 21 st century skills (P21, 2016). These skills are critically important to succeed in all areas of life and one of the most fundamental 21 st century skills is problem-solving skill

\footnotetext{
*Correspondency: muratboran@erciyes.edu.tr
} 
(PSS) (P21, 2016; World Economic Forum, 2015). Since problem-solving process is a sophisticated one that requires a high level of cognitive effort, a good problem-solver needs to have higher-order thinking skills (Demirel, 2002; Evans, 1997; Sönmez, 2015). In particular, it is essential for individuals to think critically so as to assess and evaluate a problem in a valid way consistent with scientific, cultural and social standards and criteria (Demirel, 2002; Doğanay, 2007). From this perspective, critical thinking skill might be described as the ability to form a judgment by focusing on specific goals, using cognitive elements (organizing information, questioning, conceptualizing, making meaning, inferring, making assumptions), considering mental standards (clarity, precision, subtlety, relevance), and using tendencies in the process of problem-solving and decision-making (Facione, 2011). Individuals who are willing and ready to use their critical thinking skill in appropriate or necessary situations are those with critical thinking disposition (CTD) (Tishman, Jay \& Perkins, 1993). As for their general characteristics, these individuals are self-confident, open-minded and cognitively mature. They do not accept an idea without questioning and can conduct analytical and systematic research in order to find accurate information or the cause and solution of the problems they face. Thus, CTD consists of elements such as truth-seeking, self-confidence, inquisitiveness, open-mindedness, cognitive maturity, analyticity and systematics (Facione, Facione \& Sanchez, 1994). Studies in the related literature (Faux, 1992; Halpern, 2014; Meyers, 1986; Sternberg, 1985) indicate that individuals who tend to use their critical thinking skill are capable of solving problems well by utilizing mental processes and strategies when they encounter a problem.

In addition to having CTD, individuals need to be aware of and control their cognitive processes by analyzing their own thinking process during the problem-solving process in order to become good problem-solvers (Howard, McGee, Shia \& Hong, 2000; Rudder, 2006). In other words, they should have metacognitive awareness (MA) (Howard et al., 2000; Rudder, 2006). It is pointed out in the studies (Aydurmuş, 2013; Butler \& Meichenbaum, 1981; Kaur, 1997; Knox, 2017; Mayer, 1998; Teong, 2003) that having MA significantly affects PSS since successful functioning of higher-order thinking skills depends on one's MA level (Sternberg \& Lubart, 1999). Namely, MA enables individuals to have information about their knowledge, to act with the awareness of how they learn and what they do to achieve the goal, and to know which strategies they will use for what purpose (Fauzi \& Sa'diyah, 2019; Sezgin-Memnun \& Akkaya, 2012). Individuals with MA can analyze the nature of the problem strategically and present a rational model of the factors that make up the problem. Then they can make appropriate planning to reach a solution, choose the necessary strategies and eliminate the obstacles that hinder progress by trying the possible solutions they find (Sternberg, 1985). Therefore, MA plays an important role in organizing cognitive skills such as reasoning, critical thinking and problem-solving (Karakelle \& Saraç, 2007; Senemoğlu, 2010; Young \& Worrell, 2018).

In this context, this study particularly focuses on gifted and talented (G\&T) students and their higher-order thinking skills in order to better understand and learn more about their characteristics so that their potentials can be enhanced to the highest (Trna, 2014). It can be thought that these skills can be easily demonstrated by G\&T students thanks to their intelligence and abilities (Gilmanshina, Smirnov, Ibatova \& Berechikidze, 2021). However, it is not possible to make a generalization about their PSS due to the fact that there are very few studies and there exists limited information on this subject. Nevertheless, it is mentioned in the available studies that the problem-solving strategies used by G\&T students and non-G\&T students are different (Montague, 1991; Scruggs \& Mastropieri, 1985; Uçar, 2018). There are also studies indicating that this difference is due to the fact that G\&T students use more and 
various strategies in problem-solving process (Davidson \& Sternberg, 1984; Koçyiğit, 2015). Furthermore, it is determined that G\&T students spend much time on the details and accuracy of the work while investigating the given problem and planning their solution (Davidson \& Sternberg, 1984; Shore \& Lazar, 1996), but they needed shorter time for problem-solving (Shore \& Lazar, 1996). There are also studies in the literature indicating that G\&T students use more metacognitive strategies than non-G\&T students (Coleman \& Shore, 1991; Davidson \& Sternberg, 1984; Shore, 2000; Shore \& Kanevsky, 1993). These studies revealed that G\&T students understood the problems better, made better planning while producing solutions and made more accurate evaluations when they were asked to evaluate themselves. Last but not the least, it is determined that G\&T students' creative problem-solving skills are positively and strongly related with their critical thinking skills (Karabey, 2010). Based on these study results, it can be concluded that G\&T students are effective and creative problemsolvers. However, more detailed and comprehensive research needs to be conducted on PSS of these individuals and other variables that may affect these skills.

In the related literature, no study, to the best of the researchers' knowledge, examined the relationships among G\&T students' critical thinking dispositions (CTD), perceived problemsolving skills (PPSS) and metacognitive awareness (MA). In this study, which is based on the idea of filling such a gap in the literature, it is aimed to examine relationships among CTD, PPSS and MA of G\&T students, and to test a structural equation model, which hypothesizes that CTD has a mediation effect on the relationship between PPSS and MA of G\&T students. This study is expected to be one of the steps taken in understanding G\&T students by broadening the current knowledge about them and in presenting a new perspective on their higher-order thinking skills. Besides contributing to the related literature, it is hoped that the findings of the study will not only inform curriculum experts who prepare differentiated education programs for G\&T students, but also help teachers of G\&T students understand and guide their students' development of higher-order thinking skills during their education in formal education institutions. With these in mind, answers to the following four research questions were sought:

(1) What are the levels of CTD, PPSS and MA of G\&T students?

(2) Are there statistically significant relationships among CTD, PPSS and MA of G\&T students?

(3) Do G\&T students' CTD and MA predict their PPSS?

(4) Is there a mediation effect of CTD on the relationship between PPSS and MA of G\&T students?

\section{Method}

\section{Research Design}

This study was carried out using a correlational research design in which relationships among higher-order thinking skills of G\&T students were examined and a structural equation model based on these relationships was tested (Büyüköztürk, Kılıç-Çakmak, Akgün, Karadeniz \& Demirel, 2008).

\section{Study Group}

The study group selected by using convenience sampling method consisted of 502 G\&T students who were registered to Science and Art Centers (SACs) in Adana, Kayseri and 
Mersin in 2016. 269 (53.6\%) of G\&T students were male and 233 (46.4\%) were female. The ages of the students ranged between 8 and 17, and $146(29.1 \%)$ of the students were 12 years old. $323(64.3 \%)$ of the students were studying in public schools and $179(35.7 \%)$ of them were studying in private schools. 127 (25.3\%) students from Adana SAC, 204 (40.6\%) students from Kayseri SAC and 171 (34.1\%) students from Mersin SAC participated in this study.

\section{Research Instruments and Procedures}

\section{Metacognitive Awareness Scale}

The five-point Likert-type scale, which Sperling, Howard, Miller and Murphy (2002) developed and Karakelle and Saraç (2007) adapted to Turkish, consists of 18 items loaded under one factor. Cronbach's alpha of the scale was calculated as .80 (Karakelle \& Saraç, 2007). For this study, Cronbach's alpha of the scale was calculated as .80; the fit indices obtained from Confirmatory Factor Analysis (CFA) were among the acceptance limits and the model fit was acceptable $\left(X^{2} / \mathrm{df}=4.04\right.$. $\mathrm{CFI}=.92$. NNFI=.91. RMSEA=.08. SRMR=.06) (Byrne, 2001; Hu \& Bentler, 1999; Kline, 2011).

\section{Critical Thinking Tendency Scale}

A five-point Likert-type scale, which researchers from the University of Florida developed and Ertaş-Kılıç and Şen (2014) adapted to Turkish, consists of 26 items loaded under three factors. Cronbach's alpha of the scale was calculated .91 (Ertaş-Kılıç \& Şen, 2014). For this study, Cronbach's alpha of the scale was calculated as .89; the fit indices obtained from CFA were among the acceptance limits and the model fit was acceptable $\left(X^{2} / \mathrm{df}=3.28\right.$. $\mathrm{CFI}=.94$. NNFI=.94. RMSEA=.07. $\left.\mathrm{SRMR}=.06\right)$ (Byrne, 2001; Hu \& Bentler, 1999; Kline, 2011).

\section{Problem Solving Inventory for Primary School Children}

Serin, Bulut-Serin and Saygilı (2010) developed this five-point Likert-type inventory, which consists of 24 items loaded under three factors and calculated Cronbach's alpha of the scale as .80 (Serin, Bulut-Serin \& Sayg1l1, 2010). For this study, Cronbach's alpha of the scale was calculated as .87; the fit indices obtained from CFA were among the acceptance limits and the model fit was acceptable $\left(X^{2} / \mathrm{df}=2.82 . \mathrm{CFI}=.96 . \mathrm{NNFI}=.95\right.$. RMSEA=.06. $\left.\mathrm{SRMR}=.06\right)$ (Byrne, 2001; Hu \& Bentler, 1999; Kline, 2011).

\section{Demographic Information Questionnaire}

Prepared by the authors, this questionnaire was used to collect information about students' gender and age, school types and the provinces where SACs were.

With the legal permission of the General Directorate of Special Education and Guidance Services of the Ministry of National Education of Turkey (MoNE), data collection tools were administered to students, who were informed by the researchers about the purpose of the study and willing to participate in it, in SACs in the provinces of Adana, Kayseri and Mersin in 2016. 


\section{Data Analysis}

Since the maximum likelihood estimation was used in the structural equation model, the assumptions of univariate and multivariate normality were checked and met. For an acceptable model fit, the ratio of $X^{2}$ (chi square) statistic to its degree of freedom should be 3 or less; CFI and NNFI values should be .90 or greater; RMSEA and SRMR values should be .08 or less (Byrne, 2001; Hu \& Bentler, 1999; Kline, 2011). Whether the mediation effect of the mediator variable in the structural equation model of the study was statistically significant was examined by using Bootstrap method on 5000 Bootstrap samples. In the study, .05 was used as the significance level, and Lisrel 8.7 and IBM SPSS Amos 25 programs were used in the analyses of the data.

\section{Results}

\section{Findings related to the first and second research questions}

Descriptive statistics and Pearson correlation coefficients of critical thinking dispositions (CTD), perceived problem-solving skills (PPSS) and metacognitive awareness (MA) of G\&T students are given in Table 1.

Table 1. Descriptive Statistics and Correlation Coefficients of Research Variables

\begin{tabular}{lllllll}
\hline & Mean & SD & Skewness & Kurtosis & $\mathbf{2}$ & $\mathbf{3}$ \\
\hline 1. Critical Thinking Disposition (CTD) & 4.25 & .49 & -.03 & -.14 & $.55^{* *}$ & $.73^{* *}$ \\
2. Perceived Problem-Solving Skills (PPSS) & 3.85 & .60 & -.01 & -.02 & - & $.47 * *$ \\
3. Metacognitive Awareness (MA) & 4.19 & .46 & -.03 & -.13 & - & - \\
\hline
\end{tabular}

Levels: $1-2.33=$ low; $2.34-3.66=$ medium; $3.67-5=$ high, $\mathrm{n}=502, * * \mathrm{p}<.01$

According to the means and standard deviations in Table 1, it is clear that G\&T students have high levels of CTD $(M=4.25)$, PPSS $(M=3.85)$ and MA $(M=4.19)$. According to the Pearson correlation coefficients, MA and CTD of G\&T students were positively and highly correlated with each other $(\mathrm{p}<.01)$ while they are positively and moderately correlated with PPSS $(\mathrm{p}<.01)$.

\section{Findings related to the third and fourth research questions}

The direct effects, which indicate the predictive relationships between the variables of the study, are calculated using path analyses. The standardized path coefficients, the lower and upper confidence intervals calculated by bootstrap analysis and the $\mathrm{p}$ values are given in Table 2.

Table 2. Standardized Path Coefficients Showing Predictive Relationships between Variables

\begin{tabular}{lllll}
\hline Direct Effects & $\boldsymbol{\beta}$ & Lower & Upper & p \\
\hline MA $\rightarrow$ CTD & .88 & .83 & .93 & .00 \\
CTD $\rightarrow$ PPSS & .77 & .53 & .84 & .01 \\
MA $\rightarrow$ PPSS & .67 & .45 & .77 & .00 \\
\hline
\end{tabular}

The statistics in Table 2, which are calculated before adding the mediator variable to the model, indicate that CTD increases by .88 standard deviation and PPSS increases by.67 standard deviation when MA increases by 1 standard deviation. Similarly, PPSS increases by.77 standard deviation when CTD increases by 1 standard deviation. Based on these findings, MA and CTD are found to be significant predictors of PPSS $(\mathrm{p}<.01)$. 
After the measurement model for latent variables was checked and found to be fit, the structural equation model, in which MA was the independent (exogenous) variable, CTD was the mediator variable, and PPSS was the dependent (endogenous) variable, was tested. The findings related to the model are shown in Figure 1.

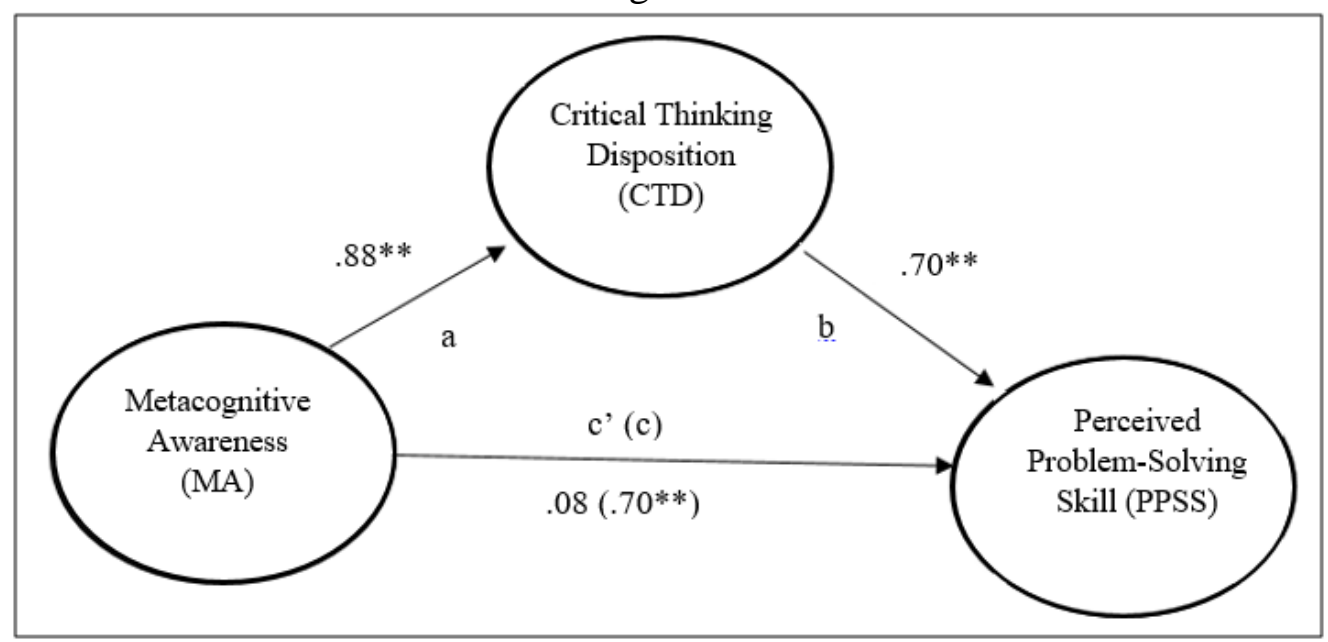

Figure 1. Diagram of the structural model $(* * \mathrm{p}<.01)$

The fit indices $\left(X^{2} / \mathrm{df}=4275.32 / 2140=1.99, \mathrm{RMSEA}=.047, \mathrm{SRM}=.063, \mathrm{CFI}=.95\right.$ and NNF with=.95) indicate that the structural model fits the data well (Byrne, 2001; Hu \& Bentler, 1999; Kline, 2011). It can be said that the basic structural model defined in this framework is verified. The statistics on the direct, indirect and total effects obtained from the verified model are given in Table 3 .

Table 3. Standardized Path Coefficients Showing Predictive Relationships between Variables When the Mediating Variable is added to the Model

\begin{tabular}{lllll}
\hline Standardized Path Coefficients & $\boldsymbol{\beta}$ & Lower & Upper & P \\
\hline Direct Effects & & & & \\
MA $\rightarrow$ CTD (a) & .88 & .83 & .93 & .00 \\
CTD PPSS (b) & .70 & .45 & 1.01 & .00 \\
MA $\rightarrow$ PPSS (c') & .08 & -.20 & .31 & .55 \\
\hline Indirect Effects & & & & \\
MA $\rightarrow$ PPSS (axb) & .62 & .43 & .91 & .00 \\
\hline Total Effects & .88 & .83 & .93 & .00 \\
MA $\rightarrow$ CTD (a) & .70 & .45 & 1.01 & .00 \\
CTD PPSS (b) & .70 & .54 & .78 & .00 \\
MA $\rightarrow$ PPSS (c $=$ axb+c') & & &
\end{tabular}

As seen in Table 3, the direct effect of MA on PPSS, which was calculated as $\beta=.67(p<.01)$ before CTD was added to the model, decreased to $\beta=.08$ and became statistically insignificant (p>.05) after CTD was added to the model as the mediating variable. It was also found that MA had an indirect effect on PPSS $(\beta=.62, p<.01)$ mediated by CTD. In other words, it was revealed that CTD had a full mediation effect on the relationship between MA and PPSS. Since the upper and lower confidence intervals calculated on the 5000 Bootstrap sample did not include zero (0), all the effects were found to be statistically significant except for the direct effect of MA on PPSS. Lastly, the coefficient of determination, which is the square of the standardized coefficient $(\mathrm{R} 2=.702=.49)$, indicated that $49 \%$ of the variance in PPSS was explained by MA when mediated by CTD. 


\section{Discussion and Conclusion}

This study aimed to examine relationships among CTD, PPSS and MA of G\&T students, and to test a structural equation model based on these relationships. The results of the study initially indicated that G\&T students had high levels of MA, CTD and PPSS. Secondly, the assumption that MA and CTDs of G\&T students can be factors affecting their PPSS was tested by constructing a theoretical structural equation model. As a result of statistical validation of the structural equation model, the assumption was found correct. In light of the findings obtained from this model, it was found out that $49 \%$ of the variance in students' PPSS was explained by their MA, and that CTD had a full mediation effect on the relationship between MA and PPSS. Based on these, it might be concluded that G\&T students who can plan, monitor and evaluate their own learning are capable of producing various solutions by using their knowledge and experience in the process of solving the problems they encounter. Likewise, it can also be concluded that these students, who do not accept the accuracy of a thought or a piece of information without questioning it and make correct decisions by using their reasoning skills, are aware that there is more than one solution to their problem and that they can eliminate the problem by choosing the best solution.

Problem-solving requires the adoption of various cognitive strategies, training of memory, learning habits and critical thinking skills. Successful functioning of all these mental structures depends on one's MA level (Sternberg \& Lubart, 1999). The findings of the studies (Aydurmuş, 2013; Mayer, 1998; Teong, 2003) also indicate that MA of students significantly affects their problem-solving skills. Artzt and Armour-Thomas (1997) also reached the conclusion that the cause of the difficulties students encountered while solving a problem were due to the fact that they could not monitor or regulate their thinking processes actively. In relation to this, Butler and Meichenbaum (1981) emphasized that problem-solving includes not only knowledge and information but also metacognitive variables that affect the way the problem is solved. Similarly, Kaur (1997) affirmed that metacognitive skills such as planning, checking, monitoring and evaluating were necessary for the problem-solving process.

The studies in the related literature point out that G\&T students solve more complicated problems much more effectively than normal students (Jaušovec, 1997) and G\&T students are more capable of using their metacognitive skills in problem-solving (Borkowski \& Peck, 1986). On the other hand, studies also reveal that G\&T students with higher MA can use learning strategies more effectively, easily learn new learning strategies, and solve problems much more effectively by adapting what they have learned to new situations they encounter (Benito, 2000; Borkowski \& Kurtz, 1987). In addition, some studies (Howard et al., 2000; Metallidou, 2009; Vukman, 2005) conclude that students' MA increases their effectiveness in problem-solving. Therefore, the findings of this study are consistent with the previous findings in the literature.

One of many distinctive features of G\&T students is that they have higher-order thinking skills such as problem-solving skill and critical thinking skill (Bapoğlu, 2010; Channel, 2000; Emir, Bülbül-Hüner \& Uzelli, 2012; İşlekeller, 2008; Kardash \& Scholes, 1996; Linn \& Shore, 2008; Sternberg, 2004). In parallel with the study results in the literature, the findings obtained from the model revealed that students' CTDs were highly effective in PPSS. Similarly, Faux (1992), as a result of his study on high school students, found out that critical thinking and intelligence predict students' problem-solving skills well. According to Sternberg (1985), critical thinking consisting of mental processes and strategies used to solve a problem starts when a problem is encountered and results in the solution of the problem (Halpern, 2014; Meyers, 1986). Another finding of this study revealed that G\&T students' CTDs had a 
full mediation effect on the relationship between their MA and PPSS. This can be interpreted as that MA enables students to find solutions to the problems they encounter by using their knowledge and experience in the process of producing solutions, while critical thinking enables them to test and evaluate these solutions. Thus, these students can produce many ideas and solve their problems with the best solution they choose by using reasoning skills (Perkins, 1988).

In conclusion, this study revealed that high levels of CTD and MA of G\&T students had positive effects on their PPSS. Based on this, it can be interpreted that these students, who can control their cognitive processes well, can produce many creative solutions by using their knowledge and strategies effectively. They can make critical decisions and overcome many complex problems by using their critical thinking and reasoning abilities to choose the best solution. As a result, it is possible to conclude that G\&T students, who are observed to have high levels of MA and CTDs, can present critical and effective solutions to many problems encountered in today's rapidly developing and changing world.

\section{Suggestions}

Based on the results of this study, some suggestions for implementation may be presented. For instance, in addition to standard education in schools, providing enriched teaching activities to meet the needs of G\&T students, who are different from students with normal development in terms of many cognitive and affective characteristics, will enable them to improve their higher-order thinking skills. Teaching methods (such as inquiry-based and project-based teaching methods and evidence-based teaching strategies) that take individual differences of G\&T students into account should be used more in the classes. Both in schools and SACs, curricula should be developed and applied according to today's models and techniques so that they can help improve the higher-order thinking skills of G\&T students. Through in-service training programs, teachers in different branches can be given information about CTD, MA and PPSS of G\&T students, and as to how they can be taught to and improved in students. In addition, with the help of monitoring and micro-teachings, teachers may be asked to design activities in this direction and apply them in their courses. Since these skills can be taught and learned, curricula can be prepared in such a way that students can be provided with rich experiences. Critical thinking skill and disposition can be taught as a course or integrated with the subject-area knowledge in each subject. In order to improve MA of their students, teachers can ask students to keep "thinking agendas" about what they know and learn in the class. With these agendas, both students and teachers can monitor and evaluate their learning and cognitive processes. Furthermore, teachers can enrich the learning-teaching process by providing students with real-life problems in classroom settings and encourage them to produce creative and effective solutions to these problems.

Some suggestions for future research may also be herein presented. To the best of the researcher's knowledge, no study examined the relationships between CTD, PPSS and MA of G\&T students. In terms of generalizability of the results, a similar study can be done with a larger sample of SACs that can represent seven different regions of Turkey. Further in-depth research can be conducted using qualitative and quantitative methods to identify other factors that may affect the problem-solving skills of G\&T students. In addition, studies can be conducted on G\&T students and non-G\&T students in order to discover whether there are any differences in their higher-order thinking skills. 


\section{Acknowledgements}

This study was produced from the master's thesis prepared by the first author under the supervision of the second author and was presented at the I. International Social Sciences Congress held in Kayseri between January 31 and February 2, 2018.

\section{References}

Artzt, A.F., \& Armour-Thomas, E. (1997). Mathematical problem solving in small groups: exploring the interplay of students' metacognitive behaviors, perceptions, and ability levels. Journal of Mathematical Behavior, 16, 63-74. doi: 10.1016/S07323123(97)90008-0

Aydurmuş, L. (2013). The examination of the 8th grade students' metacognitive skills in problem solving process. (Unpublished Master's Thesis), Karadeniz Technical University, Institute of Educational Sciences, Trabzon, Turkey. Retrieved from https://tez.yok.gov.tr/UlusalTezMerkezi/giris.jsp (Thesis Number 344467)

Bapoğlu, S. S. (2010). Examining the effects of social skills training on the gifted and talented children's peer relations. (Unpublished Doctoral Dissertation), İstanbul University, Institute of Social Sciences, İstanbul, Turkey. Retrieved from https://tez.yok.gov.tr/UlusalTezMerkezi/giris.jsp (Thesis Number 505352)

Benito, Y. (2000). Metacognitive ability and cognitive strategies to solve maths and transformation problems. Gifted Education International, 14(2), 151-159. doi: $10.1177 / 026142940001400205$

Borkowski, J. G., \& Peck, V. A. (1986). Causes and consequences of metamemory in gifted children. In R. J. Sternberg \& J. E. Davidson (Eds.), Conceptions of giftedness (pp.182-200). Cambridge, England: Cambridge University Press.

Borkowski. J. G., \& Kurtz. B. E. (1987). Metacognition and executive control. In J. G. Borkowski \& J. D. Day (Eds.), Cognition in special children: comparative approaches to retardation, learning disabilities, and giftedness (pp.123-152). Norwood. NJ: Ablex.

Butler, L., \& Meichenbaum, D. (1981). The assessment of interpersonal problem-solving skills. In P.C. Kendall \& S.D. Hollon (Eds.), Assessment strategies for cognitivebehavioral interventions (pp.197-225). New York: Academic Press.

Büyüköztürk, Ş., Kılıç-Çakmak, E., Akgün, Ö. E., Karadeniz, Ş., \& Demirel, F. (2008). Scientific research methods. Ankara: Pegem Academy Publication.

Byrne, B. M. (2001). Structural equation modeling with AMOS. Mahwah, NJ: Lawrence Erlbaum.

Carey, K. (2012, March 1) Skills, with no credential, are no longer enough. The New York Times. Retrieved from: https://www.nytimes.com/roomfordebate/2012/03/01/shouldcollege-be-for-everyone/skills-with-no-credential-are-no-longer-enough (05.12.2019)

Channel, S. W. (2000). Think different: A comparison of the critical thinking abilities of education majors. (Unpublished Doctoral Dissertation), University of Nevada. Available from ProQuest Dissertations and Theses database. (UMI No. 9973963) Retrieved from https://search.proquest.com/docview/304649574?accountid=15875

Coleman, E. B., \& Shore, B. (1991). Problem solving processes of high and average performers in physics. Journal for the Education of the Gifted, 14(4), 366-379. doi: $10.1177 / 016235329101400403$

Davidson, J. E., \& Sternberg, R. J. (1984). The role of insight in intellectual giftedness. Gifted Child Quarterly, 28(2), 58-64. doi: 10.1177/001698628402800203

Demirel, Ö. (2002). Curriculum development from theory to practice. Ankara: Pegem Academy Publication. 
Doğanay, A. (2007). Teaching higher-order thinking skills. In A. Doğanay (Ed.), Teaching principles and methods, (pp.279-231). Ankara: Pegem Academy Publication.

Emir S., Bülbül-Hüner, S., \& Uzelli O. (2012, September). Investigation of the effect of Socratic questioning method on academic success, critical thinking and metacognitive awareness levels. Paper presented at II. National Congress on Curriculum and Instruction, Abant İzzet Baysal University, Bolu, Turkey.

Ertaş-Kılıç, H., \& Şen, A. İ. (2014). Turkish adaptation study of UF/EMI critical thinking disposition instrument. Education and Science, 39(176), 1-12. doi: 10.15390/EB.2014.3632

Evans, J. R. (1997). Creativity in OR/MS: The creative problem-solving process, Part 1. Interfaces, 27(5), 78-83. Retrieved from http://www.jstor.org/stable/25062298

Facione, N.C., Facione P. A., \& Sanchez C. A. (1994). Critical thinking disposition as a measure of competent clinical judgment: the development of the California critical thinking disposition inventory. Journal of Nursing Education, 33(8), 345-350.

Facione, P. A. (2011). Critical thinking: What it is and why it counts. Insight assessment, 1, 123.

Faux, B. J. (1992). An analysis of the interaction of critical thinking, creative thinking, and intelligence with problem-solving (Unpublished Doctoral Dissertation), Temple University. Available from ProQuest Dissertations and Theses database. (UMI No. 9227458) Retrieved from https://search.proquest.com/docview/304023237?accountid=15875

Fauzi, A., \& Sa'diyah, W. (2019). Students' metacognitive skills from the viewpoint of answering biological questions: Is it already good? Indonesian Journal of Science Education, 8(3), 317-327.

Gilmanshina, S., Smirnov, S., Ibatova, A., \& Berechikidze, I. (2021). The assessment of critical thinking skills of gifted children before and after taking a critical thinking development course. Thinking Skills and Creativity, 39, 100780.

Halpern, D. F. (2014). Thought and knowledge: an introduction to critical thinking (5th ed.). New York: Psychology Press.

Howard, B. C., McGee, S., Shia, R., \& Hong, N. S. (2000, April). Metacognitive selfregulation and problem-solving: Expanding the theory base through factor analysis. Paper presented at the Annual Meeting of the American Educational Research Association, New Orleans, LA. Abstract retrieved from https://files.eric.ed.gov/fulltext/ED470973.pdf

Hu, L., \& Bentler, P. M. (1999). Cutoff criteria for fit indexes in covariance structure analysis: Conventional criteria versus new alternatives. Structural Equation Modeling: A Multidisciplinary Journal, 6(1), 1-55. doi: 10.1080/10705519909540118

İşlekeller, A. (2008). Achievements of students of above average and average intelligence in Turkish language classes focusing on critical thinking skills, and the effect of those classes on their critical thinking levels and attitudes. (Unpublished Master's Thesis), İstanbul University, Institute of Social Sciences, İstanbul, Turkey. Retrieved from https://tez.yok.gov.tr/UlusalTezMerkezi/giris.jsp (Thesis Number 261624)

Jaušovec, N. (1997). Differences in EEG alpha activity between gifted and non-identified individuals: Insights into problem solving. Gifted Child Quarterly, 41(1), 26-32. doi: $10.1177 / 001698629704100104$

Karabey, B. (2010). Determining the level of creative problem solving skills and critical thinking skills of gifted students at primary schools. (Unpublished Doctoral Dissertation), Dokuz Eylul University, Institute of Educational Sciences, İzmir, Turkey. Retrieved from https://tez.yok.gov.tr/UlusalTezMerkezi/giris.jsp (Thesis Number 265507). 
Karakelle, S., \& Saraç, S. (2007). Validity and factor structure of Turkish versions of the metacognitive awareness inventory for children (Jr. MAI) - a and b forms. Turkish Psychological Articles, 10(20), 87-103.

Kardash, C. M., \& Scholes, R. J. (1996). Effects of preexisting beliefs, epistemological beliefs, and need for cognition on interpretation of controversial issues. Journal of Educational Psychology, 88(2), 260-271. doi: 10.1037/0022-0663.88.2.260

Kaur, B. (1997). Difficulties with problem solving in mathematics. The Mathematics Educator, 2(1). 93-112. Retrieved from https://repository.nie.edu.sg/bitstream/10497/132/1/TME-2-1-93.pdf

Kline, R. B. (2011). Principles and practice of structural equation modeling (3rd ed.). New York: Guilford Press.

Knox, H. (2017). Using writing strategies in math to increase metacognitive skills for the gifted learner. Gifted Child Today, 40(1), 43-47.

Koçyiğit, N. (2015). A comparative investigation of problem solving approaches of gifted and non-gifted middle school students. (Unpublished Master's Thesis, Erciyes University, Institute of Educational Sciences, Kayseri, Turkey. Retrieved from https://tez.yok.gov.tr/UlusalTezMerkezi/giris.jsp (Thesis Number 418049)

Linn, B., \& Shore, B. M. (2008). Critical thinking. In J. A. Plucker \& C. M. Callahan (Eds.), Critical issues and practices in gifted education: What the research says (pp.155165). Waco, TX: Prufrock Press.

Mayer, R.E. (1998). Cognitive, metacognitive and motivational aspects of problem solving. Instructional Science, 26,(1-2), 49-63. doi: 10.1023/A:1003088013286

Metallidou, P. (2009). Pre-service and in-service teachers' metacognitive knowledge about problem-solving strategies. Teaching and Teacher Education, 25(1), 76-82. doi: 10.1016/j.tate.2008.07.002

Meyers, C. (1986). Teaching students to think critically: A guide for faculty in all disciplines. San Francisco: Jossey-Bass.

Montague, M. (1991). Gifted and learning-disabled gifted students' knowledge and use of mathematical problem-solving strategies. Journal for the Education of the Gifted, 14(4), 393-411. doi: 10.1177/016235329101400405

Partnership for 21st Century Skills. (2016). Framework for 21st century learning. Retrieved from http://www.p21.org/ourwork/p21-framework.

Perkins, D. N. (1988). Creativity and the quest for mechanism. In R. J. Sternberg, \& E. E. Smith (Eds.), The psychology of human thought. (pp. 309-336). New York, NY: Cambridge University Press.

Rudder, C. A. (2006). Problem solving: Case studies investigating the strategies used by secondary American and Singaporean students (Unpublished Doctoral Dissertation), Florida State University. Available from ProQuest Dissertations \& Theses. (UMI No. 3232443). $\quad$ Retrieved from https://search.proquest.com/docview/305332409?accountid=15875

Scruggs, T. E., \& Mastropieri, M. A. (1985). Spontaneous verbal elaboration in gifted and nongifted youths. Journal for the Education of the Gifted, 9(1), 1-10. doi: $10.1177 / 016235328500900102$

Senemoğlu, N. (2010). Development, learning and instruction: From theory to application. Ankara: Pegem Academy Publication.

Serin, O., Bulut-Serin, N., \& Sayg1l1, G. (2010). Developing problem solving inventory for children at the level of primary education (PSIC). Elementary Education Online, 9(2), 446-458.

Sezgin-Memnun, D., \& Akkaya, R. (2012). An investigation of pre-service primary school mathematics, science and classroom teachers' metacognitive awareness in terms of 
knowledge of and regulation of cognition. Journal of Theoretical Educational Science, 5(3), 312-329. Retrieved from https://dergipark.org.tr/download/article-file/304195.

Shore, B. M. (2000). Metacognition and flexibility: Qualitative differences in how gifted children think. In R. C. Friedman \& B. M. Shore (Eds.), Talents unfolding: Cognition and development (pp. 167-187). Washington, DC, US: American Psychological Association. doi: 10.1037/10373-008

Shore, B. M., \& Kanevsky, L. S. (1993). Thinking processes: Being and becoming gifted. In K. A. Heller, F. J. Mönks, \& A. H. Passow (Eds.), International handbook of research and development of giftedness and talent (pp.133-147). Oxford: Pergamon Press.

Shore, B. M., \& Lazar, L. (1996). IQ-related differences in time allocation during problem solving. Psychological Reports, 78(3), 848-850. Retrieved from https://journals.sagepub.com/doi/pdf/10.2466/pr0.1996.78.3.848.

Sönmez, V. (2015). Educational Philosophy (14th ed.). Ankara: Anı Publication.

Sperling, R. A., Howard, B. C. Miller, L. A., \& Murphy, C. (2002). Measures of children's knowledge and regulation of cognition. Contemporary Educational Psychology, 27, 51-79. doi:10.1006/ceps.2001.1091

Sternberg, R. J. (1985). Cognitive approaches to intelligence. In B. B. Wolman (Ed.), Handbook of intelligence: theories, measurements and applications (pp. 59-118). New York: Wiley.

Sternberg, R. J. (2004). Why smart people can be so foolish. European Psychologist, 9(3), 145-150. doi: 10.1027/1016-9040.9.3.145

Sternberg, R. J., \& Lubart, T. I. (1999). The concept of creativity: Prospects and paradigms. In R. J. Sternberg (Ed.), Handbook of creativity (pp. 3-15). New York: Cambridge University Press.

Teong, S. K. (2003). The effect of metacognitive training on mathematical word-problem solving. Journal of Computer Assisted Learning, 19(1), 46-55. doi: 10.1046/j.02664909.2003.00005.x

Tishman, S., Jay, E., \& Perkins, D. N. (1993). Teaching thinking dispositions: From transmission to enculturation, Theory into Practice, 32(3), 147-153. doi: $10.1080 / 00405849309543590$

Trna, J. (2014). IBSE and gifted students. Science Education International, 25(1), 19-28.

Ucar, F. M. (2018). Investigation of gifted students' epistemological beliefs, self-efficacy beliefs and use of metacognition. Journal for the Education of Gifted Young Scientists, 6(3), 1-10. doi: http://dx.doi.org/10.17478/JEGYS.2018.77

Vukman, K. B. (2005). Developmental differences in metacognition and their connections with cognitive development in adulthood. Journal of Adult Development, 12(4), 211221. doi: 10.1007/s10804-005-7089-6

World Economic Forum. (2015). The Global Competitiveness Report 2015-2016. Geneva: World Economic Forum. Retrieved from http://www3.weforum.org/docs/gcr/20152016/Global_Competitiveness_Report_2015-2016.pdf.

Young, A., \& Worrell, F. (2018). Comparing metacognition assessments of mathematics in academically talented students. Gifted Child Quarterly, 62(3), 259-275. 